\title{
DROP TESTS OF PROTOTYPE CUBE AND CUBIPOD ARMOR UNITS
}

\author{
Antonio Corredor ${ }^{1}$, Rafael Torres ${ }^{1}$, Juan V. Miñana ${ }^{1}$, Enrique Fernández ${ }^{1}$, Carlos F. \\ Menéndez ${ }^{1}$, Moisés Santos ${ }^{1}$, M. Esther Gómez-Martín ${ }^{2}$ and Josep R. Medina ${ }^{3}$
}

\begin{abstract}
The structural strength of concrete armor units (CAUs) is a key factor in the design and construction of armor layers for large mound breakwaters. This paper describes the prototype drop tests carried out to assess the structural strength of conventional cube and Cubipod CAUs. Low intensity overturning tests, high intensity free fall tests and extreme intense free fall tests were conducted to measure the structural integrity under impact loads of the Cubipod CAU compared to the conventional cubic block. The casting systems and pressure clamps were specifically designed to manufacture and handle the 15-tonne conventional cube and 16-tonne Cubipod prototypes used for the drop tests. Two reinforced-concrete platforms were used for overturning and free fall tests. The 16-tonne Cubipod prototypes withstand drops more than 50\% higher than 15-tonne conventional cube prototypes of similar concrete strength. Two extreme free fall tests verified the robustness of Cubipod prototypes in accidental falls during construction. Both Cubipod and conventional cube CAUs have similar stacking and handling procedures as well as manufacturing cycle time.
\end{abstract}

Keywords: rubble-mound breakwater; armor unit; Cubipod; drop test; prototype test; concrete block

\section{INTRODUCTION}

Armor erosion due to wave attack is the most critical failure mode in rubble-mound breakwater design. During the 19th century, cubes and parallelpiped concrete armor units (CAUs) were used worldwide, when local quarries did not provide the appropriate stone size. Since 1950, many different CAUs have been developed to improve the hydraulic stability of the armor layer in large mound breakwaters. It was, nonetheless, the catastrophic failure of the 40-tonne Dolos armored breakwater at the Port of Sines (Portugal) in 1978 that focused engineers' attention on CAU structural integrity. The larger the CAU prototype, the more fragile it is, because static loads tend to be proportional to the third power while resistant sections only to the second power. Therefore, modern CAU designs balance hydraulic stability and structural strength. Fig. 1 shows some of the existing types of CAUs mentioned by Dupray and Roberts (2009), which are classified according to the structural strength: massive, bulky and slender. This paper describes prototype drop tests with cubes and Cubipods, which both belong to the massive CAU category.

\section{Cube}
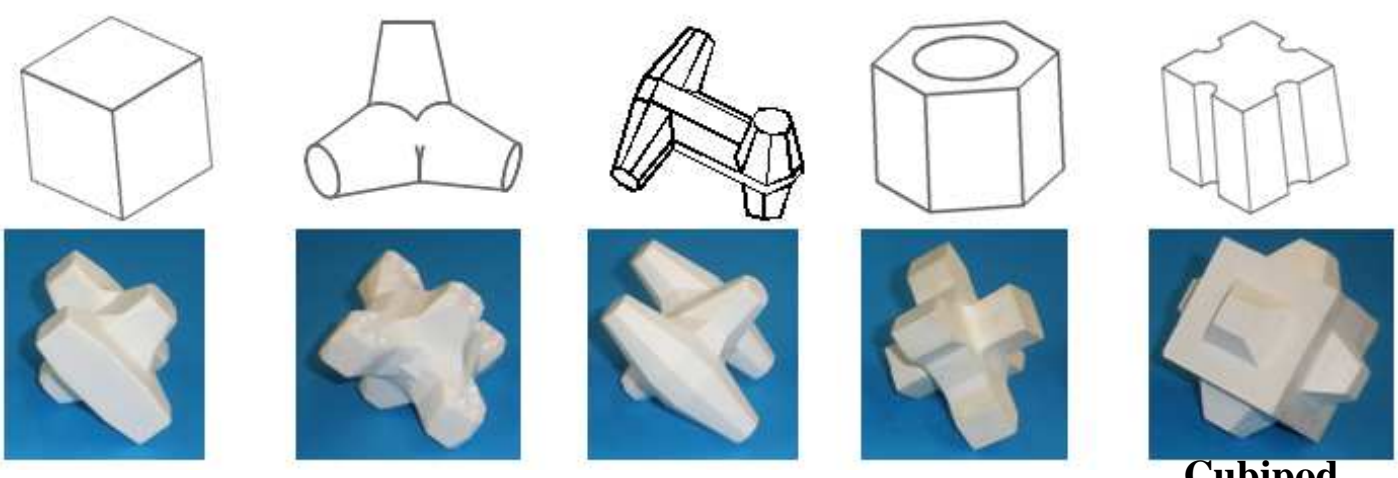

Figure 1. Concrete armor units (CAUs).

The catastrophic failure due to unit breakage in Sines (Portugal) and later in San Ciprián (Spain) prevented the continued use of slender units in Spain. Cube and parallelepiped armor units have been used extensively along the Spanish Atlantic coast (Bilbao, Gijón, La Coruña, etc.) given their clear advantages: high structural strength, simple casting, easy and safe handling with pressure clamps,

${ }^{1}$ SATO (OHL Group), Paseo de la Castellana 259-D-8o, "Torre Espacio”, 28046 Madrid, Spain. Dept.
Transportation, Universidad Politécnica de Valencia, Camino de Vera s/n, 46022 Valencia, Spain
${ }^{2}$ Dept. Construction, Universidad de Alicante, San Vicente del Raspeig, 03690 Alicante, Spain
${ }^{3}$ Dept. Transportation, Universidad Politécnica de Valencia, Camino de Vera s/n, 46022 Valencia, Spain 
efficient stacking, etc. On the Spanish coast, the largest breakwaters are armored with conventional cube CAUs, each weighing more than 100 tonnes, as in the case of the 150-tonne unreinforced cubes used at La Coruña (Spain) (Burcharth et al. 2002). Nevertheless, researchers like Gómez-Martín and Medina (2008), recognize the drawbacks of cube CAUs: face-to-face packing, low friction with the filter layer and low hydraulic stability.

Gómez-Martín and Medina (2008) also provide details regarding the Cubipod, a new CAU designed to maintain the advantages of the cube CAU while correcting the drawbacks. Both single-layer and double-layer Cubipod armors have much higher hydraulic stability and lower overtopping rates than conventional double-layer cube armors. Prototype drop test results of cube and Cubipod CAUs indicate that Cubipods resisted higher drops than cubic blocks of similar size and the same concrete supply (Medina et al. 2009). Therefore, by replacing conventional cubes with Cubipods the breakwater construction and maintenance costs are significantly reduced.

Conventional cubes and Cubipods are massive CAUs which can be efficiently handled using pressure clamps, as shown in Fig. 2. Both can be manufactured using vertical molds at a production rate of 2 units/day and can be stacked in a similar way in low porosity block yards. In short, cubic block and Cubipod CAUs are similar from the logistics point of view.
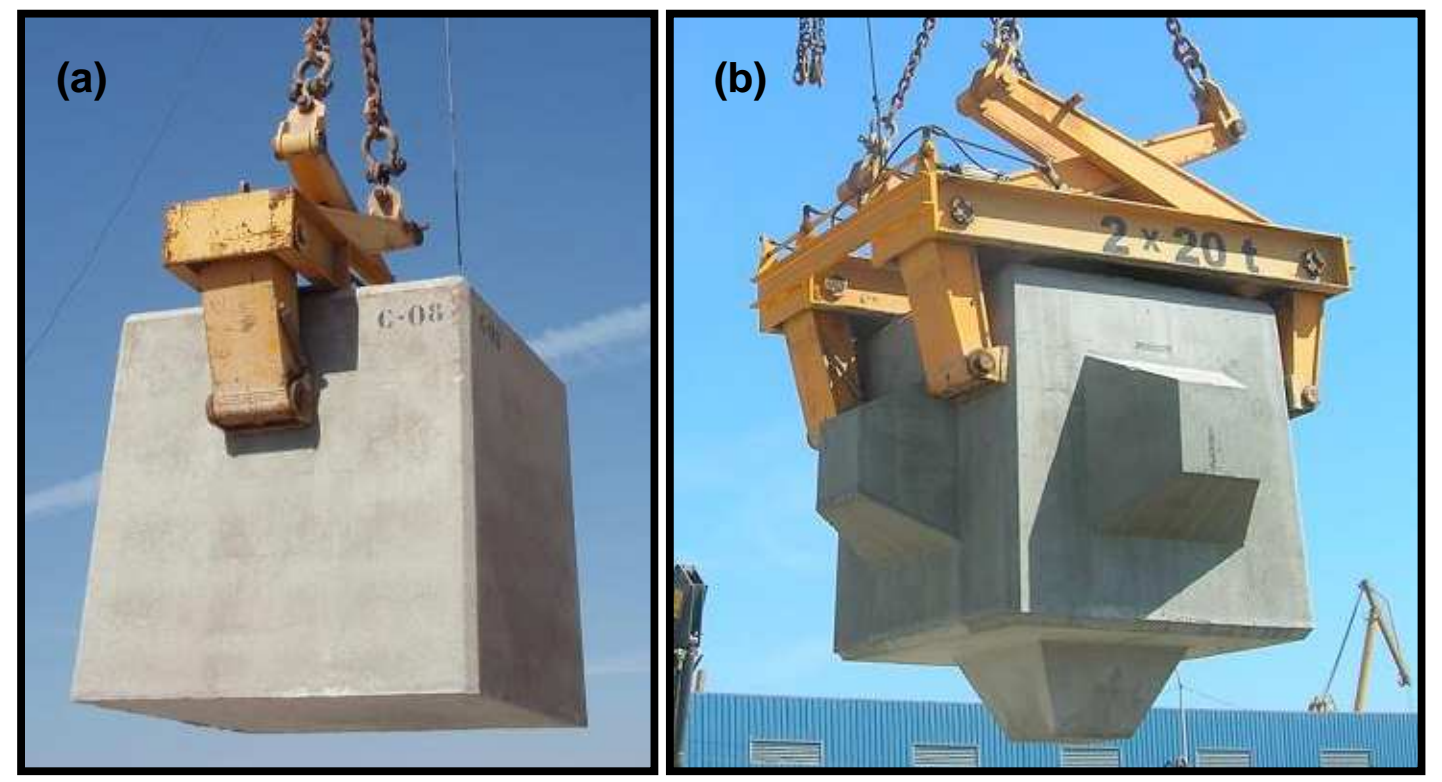

Figure 2. Prototype CAUs handled with pressure clamps: (a) cubic block and (b) Cubipod.

To assess the structural strength of the Cubipod armor unit, conventional cubic blocks and Cubipods of approximately $7 \mathrm{~m}^{3}$ were compared through a series of prototype drop tests. This paper describes the prototype drop tests of cube and Cubipod CAUs conducted during the first week of March 2008 in the SATO block yard at the Port of Alicante (Spain).

\section{ARMOR UNIT INTEGRITY AND IMPACT EXPERIMENTS AT PROTOTYPE SCALE}

Hanzawa et al. (2006) reported on the use of reinforced-concrete Tetrapods and Dolosse up to 80 tonnes in Japan. However, unreinforced CAUs are much cheaper than reinforced ones and are preferred worldwide; nevertheless, CAU integrity must be guaranteed during construction and service time. The structural resistance of CAUs depends not only on the concrete supply specifications but also on the static, hydrodynamic and impact loads affecting the CAUs. Impact loads on CAUs are numerous in breakwater lifetime: during transport, handling and placement during construction and collisions due to rocking CAUs in service time.

CAU integrity is a concept associated with the mechanical strength of the unit. Structural damage results from a variety of loads on CAUs; however, the variables affecting CAU integrity are so numerous that it is not possible to quantify the structural integrity even for simple massive CAUs such as conventional cubes or Cubipods. Therefore, it is reasonable to simplify the CAU integrity characterization problem by reducing the number of variables and scenarios to be considered. 
A review of the methodologies used to assess the structural integrity of different CAUs highlights the significant elements to be considered in the experiments related to CAU integrity. Available testing facilities, CAU shape, and personnel and financial resources are key elements to be considered in experimental design. Lillevang and Nikola et al. (1976) used 3D photoelastic stress analysis to study the breakage of Dolosse, suggesting a number of static loading tests to estimate large-size Dolos stress concentration. Burcharth (1981) used dimensional analysis and proposed specific prototype drop tests and impact tests to rationalize the relationship between CAU size and structural integrity; unreinforcedconcrete as well as reinforced-concrete Dolos up to 5.4 tonnes were used. Burcharth and BrejnegaardNielsen (1986) pointed out that the maximum stress level in CAUs due to impacts were roughly proportional to the squared root of the CAU size. Nishigori et al. (1989) analyzed the similarity laws of stresses caused by impacts on concrete Tetrapods. Burcharth et al. (2000) examined scaling laws for a variety of static, hydrodynamic and impact loads proposing empirical formulae to estimate the number of broken Dolosse and Tetrapods in prototype situations. Small-scale slender CAUs have also been tested using internal load cells and surface-mounted strain gauges to measure CAU stresses. To measure bending moments and torque at prototype scale, 36-tonne Dolosse CAUs were internally instrumented at Crescent City jetty (California).

In order to represent prototype CAU handling and stacking, 3D Finite Element Method (FEM) has been used with static load scenarios. For example Melby and Turk (1995) compared FEM results for Tribar, Dolos, Accropode and Core-Loc units while Hakenberg et al. (2004) compared FEM results of Accropode, Core-Loc and Xblocs. The dynamic FEM models have also been used to determine concrete stress in CAUs. However, static and dynamic FEM models have several inadequacies when representing real conditions: the limited number of man-prescribed static loads which can be analyzed, the sensitivity of dynamic FEM models to numerical material parameters and platform stiffness as well as the assumed impact conditions. Recently, a combined Finite-Discrete Element Method proposed by Latham and Xiang (2009) used a more realistic elastic-plastic constitutive, contact friction and other characteristics to create appropriate simulators because elastic idealized models significantly overestimate internal maximum tensile stress caused by impacts to CAUs.

Numerical models and small-scale drop tests and strain measurements are not very reliable to assess CAU integrity at prototype scale; therefore, experimental impact tests at prototype scale are considered more realistic. Burcharth (1981) tested 1.5-tonne and 5.4-tonne Dolosse; Silva (1983) tested 1-tonne to 27-tonne cubes; Nishigori et al. (1989) tested 2 to 4-tonne Tetrapods; Turk and Melby (1998) tested 9-tonne Core-Locs and 11-tonne Dolosse. Muttray et al. (2004) described the drop test results corresponding to 9-tonne Xblocs, 9-tonne Core-Locs and 15-tonne Accropodes. In this paper, overturning and free fall tests using 15-tonne conventional cubes and 16-tonne Cubipods, described with specific details by Medina et al. (2010), are examined.

\section{MOLD AND CUBIPOD CASTING SYSTEM}

In order to efficiently manufacture Cubipod CAUs at prototype scale, it was necessary to design a casting system to optimize the CAU manufacturing cycle. The engineers and technicians of the Spanish construction company SATO designed a special casting system (P200702396 Spanish Patent) to manufacture two units per day as is the case of conventional cubic blocks. Additionally, Cubipodadapted pressure clamps were designed for the efficient handling of the 16-tonne Cubipods during the prototype drop tests (see Corredor et al. 2008). Unreinforced 16-tonne Cubipod and 15-tonne cube CAUs were used to evaluate the structural strength of cubes and Cubipods. Fig. 2 shows the pressure clamps used during the prototype drop tests and Fig. 3 shows the casting system designed by SATO as well as Cubipod and conventional cube prototypes stacked and ready to be used for drop tests. The base sustains the weight of the armor unit, and the mold can be lifted six hours after concrete filling and vibration.

A mold to manufacture 16-tonne Cubipods $\left(7.1 \mathrm{~m}^{3}\right)$ and a conventional mold for 15-tonne cubic blocks were placed at SATO's block yard in the Port of Alicante. Conventional cubic blocks and Cubipod prototypes were manufactured using the same source of concrete and similar handling, curing and vibration procedures. The Cubipod casting system has two parts: (1) a static base and (2) an upper part with six articulated elements; the concrete is poured and vibrated in two phases. The upper part can be lifted six hours after vibration. Fig. 4 shows two bases and an upper part with articulated elements.

To manufacture Cubipod CAUs, the upper part is placed on one of the bases with the four lower articulated elements closed. More than $95 \%$ of the concrete is poured first into the mold and then vibrated just like conventional cubes. Once the first-phase vibration is completed, the higher articulated 
elements are closed and the remaining concrete is poured into the mold and vibrated. After the six-hour hardening phase, the articulated elements can be opened and the upper part of the mold can be lifted and moved onto another base to repeat the operation.

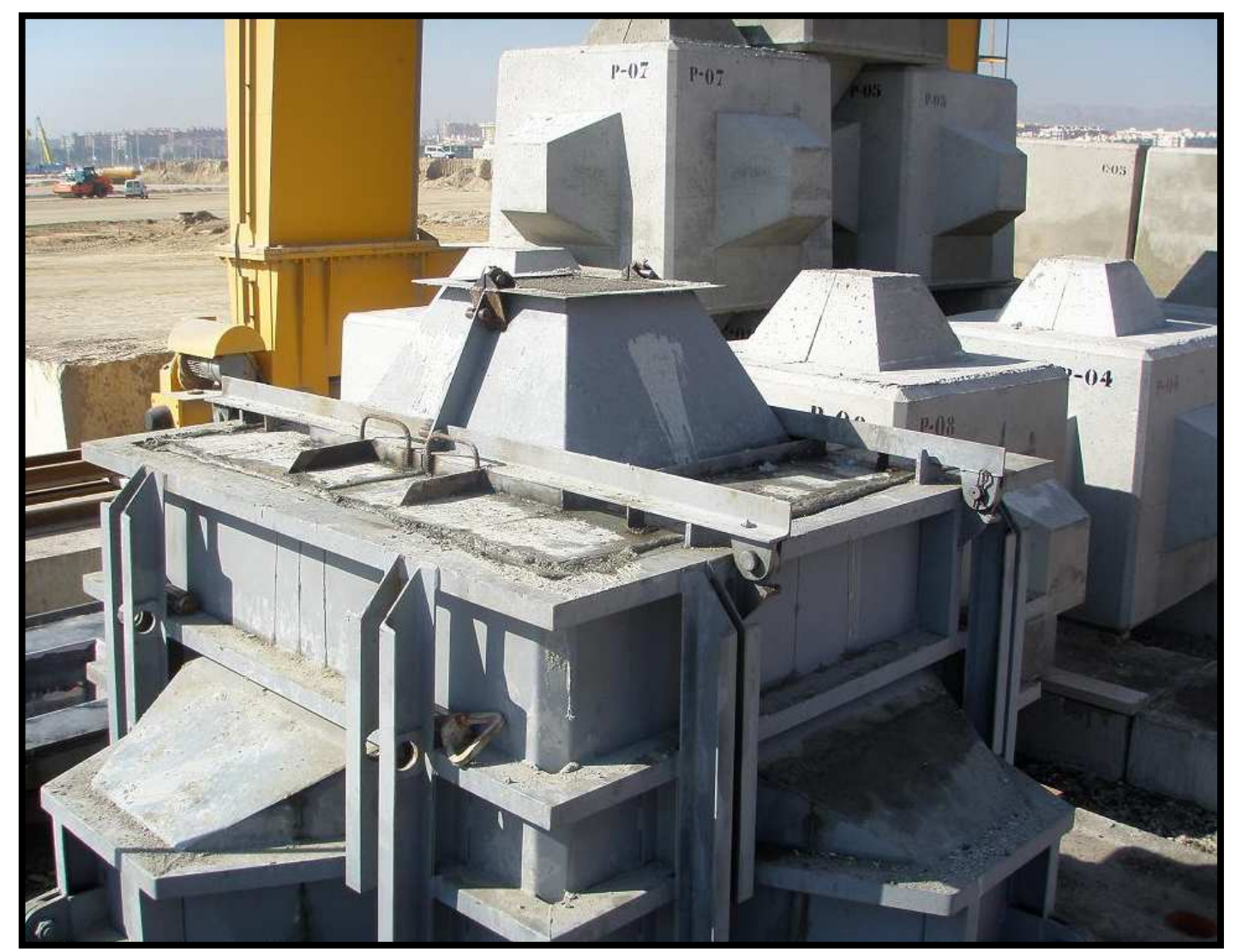

Figure 3. Cubipod mold and stacked CAUs.

To facilitate the mold lifting operations and thus obtain the same production cycle as the conventional cube, it is necessary to design the mold with a slight pyramidal shape to eliminate vertical faces. Fig. 5 shows the actual dimensions of the 16-tonne Cubipod designed for these prototype drop tests.
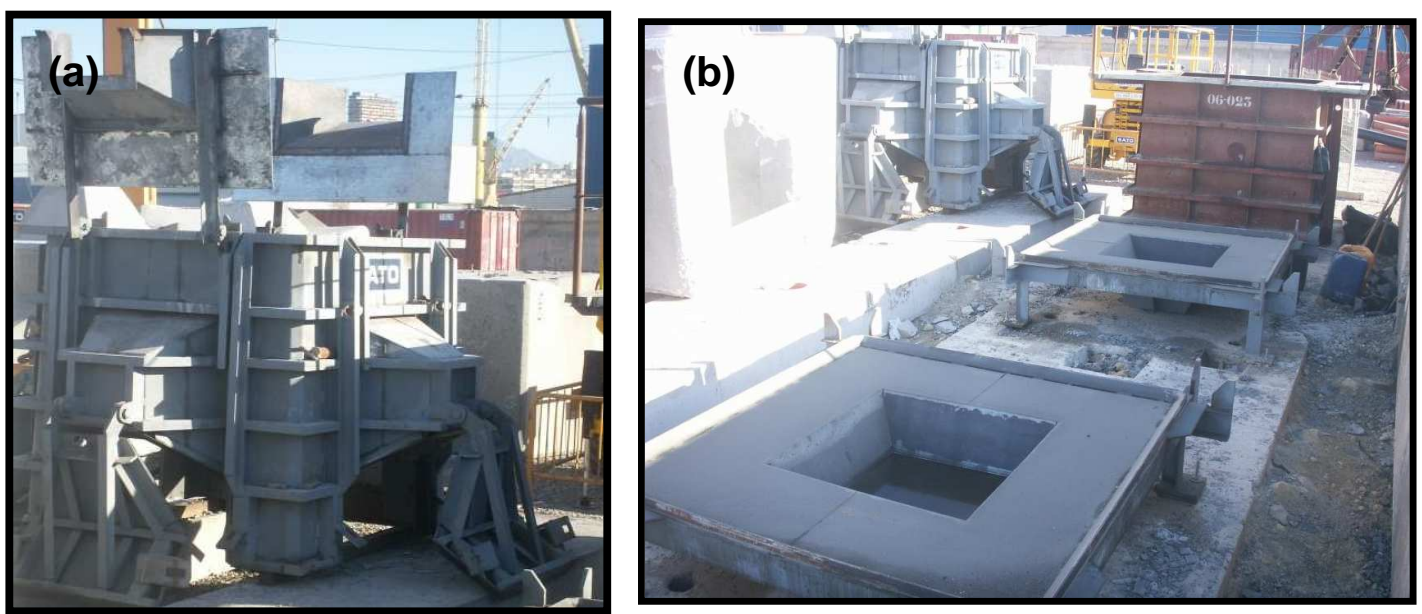

Figure 4. Cubipod casting system: (a) articulated upper part and (b) bases. 


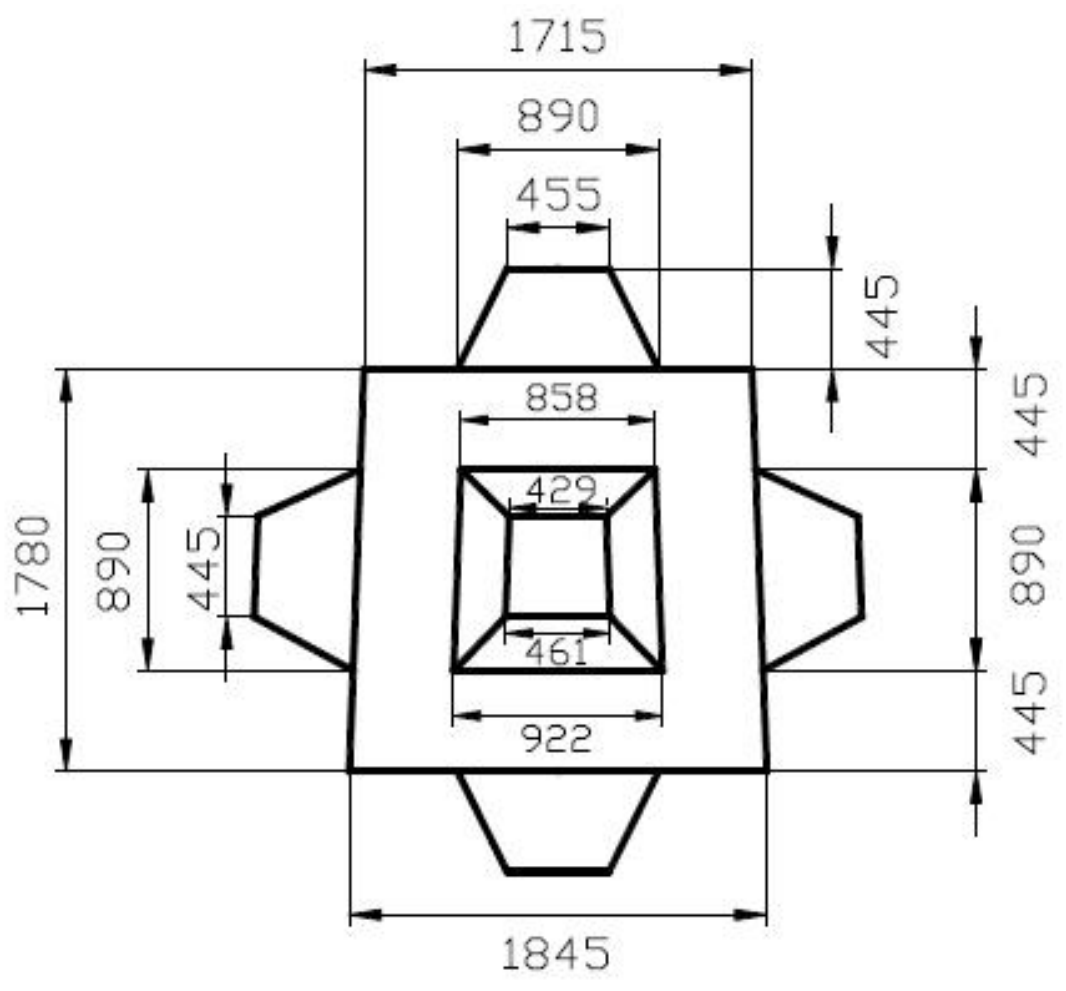

Figure 5. 16-tonne Cubipod dimensions $(\mathrm{mm})$ for the 2008 prototype drop tests.

\section{PROTOTYPE IMPACT EXPERIMENTS}

In order to assess the structural strength of Cubipod CAUs, overturning, free fall and extreme free fall tests were carried out. Eight unreinforced 15-tonne conventional cubic blocks and eleven unreinforced 16-tonne Cubipods were produced using similar manufacturing procedures and the same concrete mix source to fill the molds. Overturning was tested on a $90 \mathrm{~cm}$-thick reinforced-concrete platform while free fall tests (drop types: anvil, edge and random) were carried out on a $115 \mathrm{~cm}$-thick reinforced-concrete platform protected by a $20 \mathrm{~mm}$-thick steel plate. Both platforms were constructed on highly compacted soil in the Port of Alicante's block yard. A 63/25-tonne gantry crane and 20-tonne single tongs as well as $2 \times 20$-tonne double tongs were used to handle and drop the prototypes. The detailed description of methodology and results for these tests are given by Medina et al. (2010) and are comparable to overturning and free fall tests with other CAUs (see Muttray et al. 2005). Fig. 6 shows the reinforced-concrete platforms used for overturning and free fall tests.

\section{Overturning tests}

In order to determine the effects of low intensity impacts on cube and Cubipod CAUs, four Cubipod and two cube prototypes were tested for frontal and diagonal maneuvers as well as partial and complete overturning maneuvers, respectively. A wheeled excavator tipped the 15-tonne cubic blocks for partial $\left(15^{\circ}\right)$ and complete $\left(45^{\circ}\right)$ overturning tests. 16-tonne Cubipods were overturned in a similar way; the wheeled excavator pushed the Cubipod prototypes for overturning. If the wheeled excavator's force was applied to the vertical symmetry plane, frontal overturning was tested; if the force was asymmetric, diagonal overturning was tested.

Overturning tests were conducted on the $90 \mathrm{~cm}$-thick reinforced-concrete platform $(10.0 \times 7.5)$ shown in Fig. 6a. The Relative Loss of Mass (RLM) was minor for cubes (RLM<2\%) and almost negligible for Cubipods (RLM<0.3\%). Fig. 7 shows overturning maneuvers of prototypes. The damage to the overturning reinforced-concrete platform $(10.0 \times 7.5 \times 0.9 \mathrm{~m}$.) was negligible. The four Cubipod prototypes with negligible damage used for the overturning tests later served as the group of prototype receptors during the extreme free fall tests. 

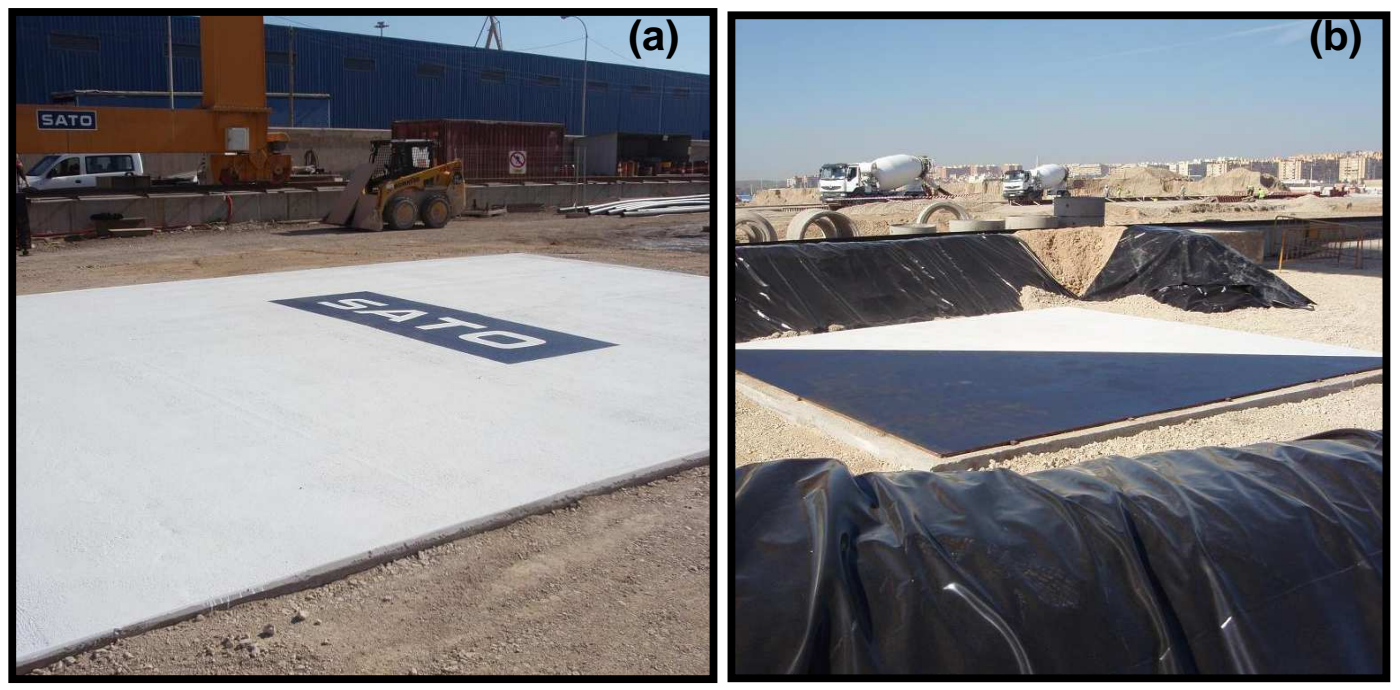

Figure 6. Reinforced-concrete platforms: (a) Overturning tests and (b) Free fall tests.
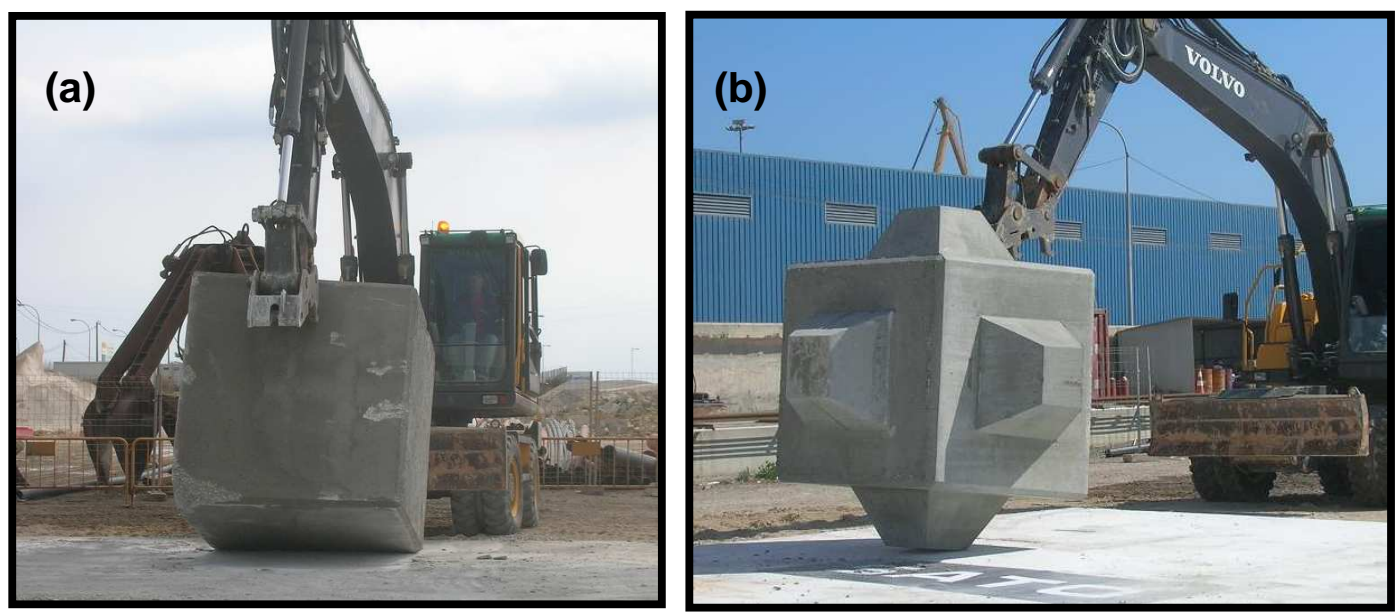

Figure 7. Maneuvers: (a) Cube partial overturning and (b) Cubipod frontal overturning.

\section{Free fall tests}

In order to assess the CAU structural strength to high energy impacts, three different types of free fall tests were carried out on the $115 \mathrm{~cm}$-thick reinforced-concrete platform (5.0x5.0) protected by the 20 mm-thick steel plate shown in Fig. 6b: Anvil Drop (AD), Edge Drop (ED) and Random Drop (RD). $\mathrm{AD}$ means the prototype was dropped with one of its faces parallel to the platform and ED means the prototype was rotated $45^{\circ}$ and dropped with one edge parallel to the platform. Finally, for RD tests, the prototype was suspended from the gantry crane touching the top of a cubic block placed on the ground and then dropped. AD generates a face-to-face translation impact, ED generates an edge-to-face translation impact, and RD generates an unpredictable fall with translation and rotation impact. Fig. 8 shows the schematic representation of AD, ED and RD tests. For both cubic blocks and Cubipods, AD caused more damage than ED while ED was more damaging than RD.

$A D$

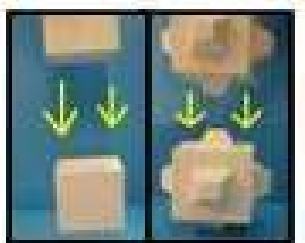

ED

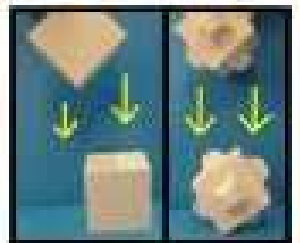

RD

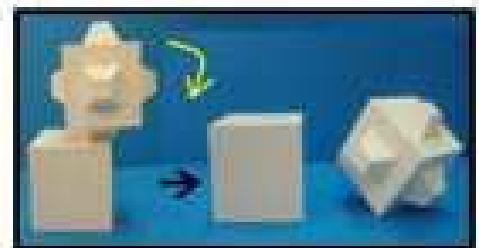

Figure 8. Free fall tests: (AD) Anvil Drop, (ED) Edge Drop and (RD) Random Drop. 
Each CAU prototype was dropped up to six times from the drop height $(\mathrm{h}[\mathrm{m}])$ in an $\mathrm{AD}$, ED or RD test. Each CAU prototype was weighed to calculate RLM after each drop. Cubic blocks in AD from $\mathrm{h}[\mathrm{m}]=0.5$ and $1.0 \mathrm{did}$ not break after six drops, showing $\mathrm{RLM}=1.4 \%$ and $3.6 \%$, respectively. Cubic blocks in $\mathrm{AD}$ from $\mathrm{h}[\mathrm{m}]=1.5$ and 2.0 were broken apart $(\mathrm{RLM}=32.5 \%$ and $45.0 \%)$ after the third $(\mathrm{n}=3)$ and first $(n=1)$ drop, respectively. Fig. 9 shows images of the $A D$ test with $h[m]=2.0$. The cube prototype dropped in ED from $\mathrm{h}[\mathrm{m}]=2.0$ was broken after the second $(\mathrm{n}=2)$ drop with $\mathrm{RLM}=32.0 \%$. The cube prototype in RD from the top a cubic block with $\mathrm{h}[\mathrm{m}]=1.9$ was broken with the third $(\mathrm{n}=3)$ drop $(\mathrm{RLM}=26.7 \%)$.

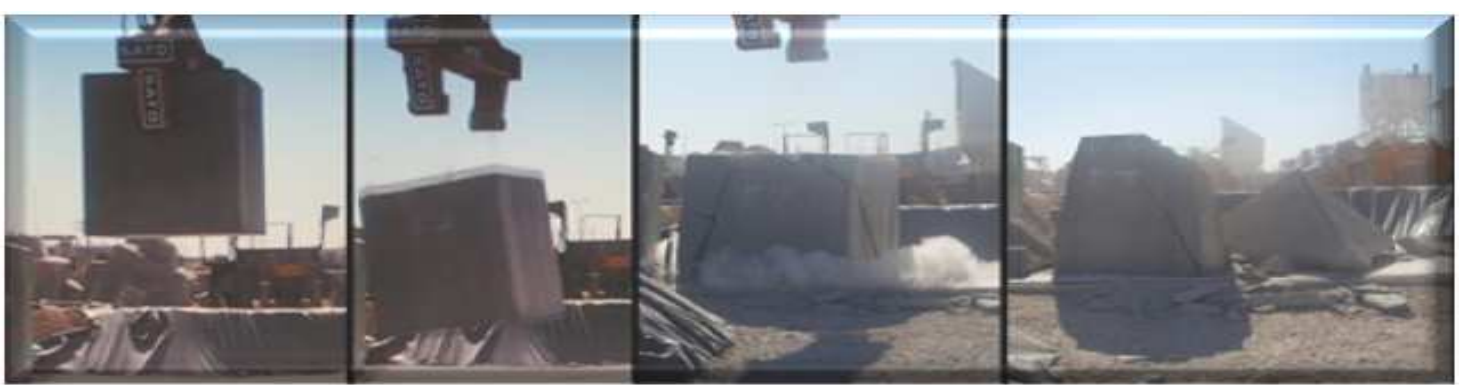

Figure 9. Anvil Drop (AD) of conventional cubic block CAU $(h[m]=2.0, n=1)$.

The Cubipod prototype dropped in the AD test from $\mathrm{h}[\mathrm{m}]=2.0$ was broken with the last $(\mathrm{n}=6)$ drop $(\mathrm{RLM}=20.3 \%)$. Cubipod prototypes dropped in $\mathrm{ED}$ and $\mathrm{RD}$ from $\mathrm{h}[\mathrm{m}]=2.0$ did not break after six drops, showing a maximum RLM $=3.1 \%$ and $3.5 \%$, respectively.

Corredor et al. (2008) suggested using an equivalent drop height, $h_{e}$, given by Eq. 1 to take into consideration the drop height as well as the number of drops. The new variable $h_{e}$ is the equivalent drop height; $h$ is the drop height, and $n$ is the number of drops.

$$
h_{e}=h *(n)^{0.25}
$$

When the RLM results described above are analyzed from the viewpoint of the equivalent drop height, $h_{e}$, there are two clearly distinguishable CAU performances, above and below RLM $=4 \%$. There is a different critical equivalent drop height, $h_{\mathrm{ec}}$ for each CAU which produces a $\mathrm{RLM}=4 \%$. Below this critical value, $h_{e}<h_{e c}$ and $R L M<4 \%$, the damage to the CAU increases almost linearly with $h_{e}$; the damage does not affect the CAU core but only the edges and periphery without changing significantly the original CAU morphology. On the contrary, once the critical value is surpassed, $h_{e}>h_{e c}$ and RLM $>>4 \%$, the damage to the CAU increases abruptly, leading to CAU core breakage and altering significantly the original CAU morphology.

In summary, RLM depended on CAU type (cube or Cubipod), drop type (AD, ED or RD), drop height (h) and number of repetitions (n); when RLM exceeded 4\%, unit breakage occurred in both cubes and Cubipods. 16-tonne Cubipod prototypes withstood drops over 50\% higher than conventional 15-tonne cube prototypes. Fig. 10 shows the RLM of AD free fall tests (cubes) and AD, ED and RD free fall tests (Cubipods) as function of the equivalent drop height, $R L M\left(h_{e}\right)$. The critical equivalent drop heights were $h_{\mathrm{ec}}[\mathrm{m}]=1.9$ for cubes and $h_{\mathrm{ec}}[\mathrm{m}]=3.1$ for Cubipods. Although the Cubipod prototypes were slightly larger than the cubes, the concrete mix source was the same, and Cubipod prototypes clearly withstood higher drops. To explain the different performance of cubes and Cubipods, Corredor et al. (2008) suggested the loss of energy from small local and edge damage which reduces the acceleration of the CAU core and the corresponding risk of breakage in the case of Cubipod prototypes.

The reinforced-concrete free fall platform $(5.0 \times 5.0 \times 1.15 \mathrm{~m}$.) protected with a $20-\mathrm{mm}$ steel plate accumulated small cracks and damages during the free fall tests. The platform was in good condition during most of the above experiments, showing some damages in a few cube drop tests (AD with $\mathrm{h}[\mathrm{m}]=1.0$ and 1.5 and $\mathrm{RD}$ with $\mathrm{h}[\mathrm{m}]=1.9$ ). However, when a Cubipod prototype was dropped from $\mathrm{h}[\mathrm{m}]=3.0$, the platform rapidly accumulated damage while the CAU suffered negligible damage. It was obvious that the energy of the impact was consumed damaging the platform instead of the 16-tonne Cubipod prototype. Therefore, the latest data from $\mathrm{h}[\mathrm{m}]=3.0$ were not considered for this analysis. 


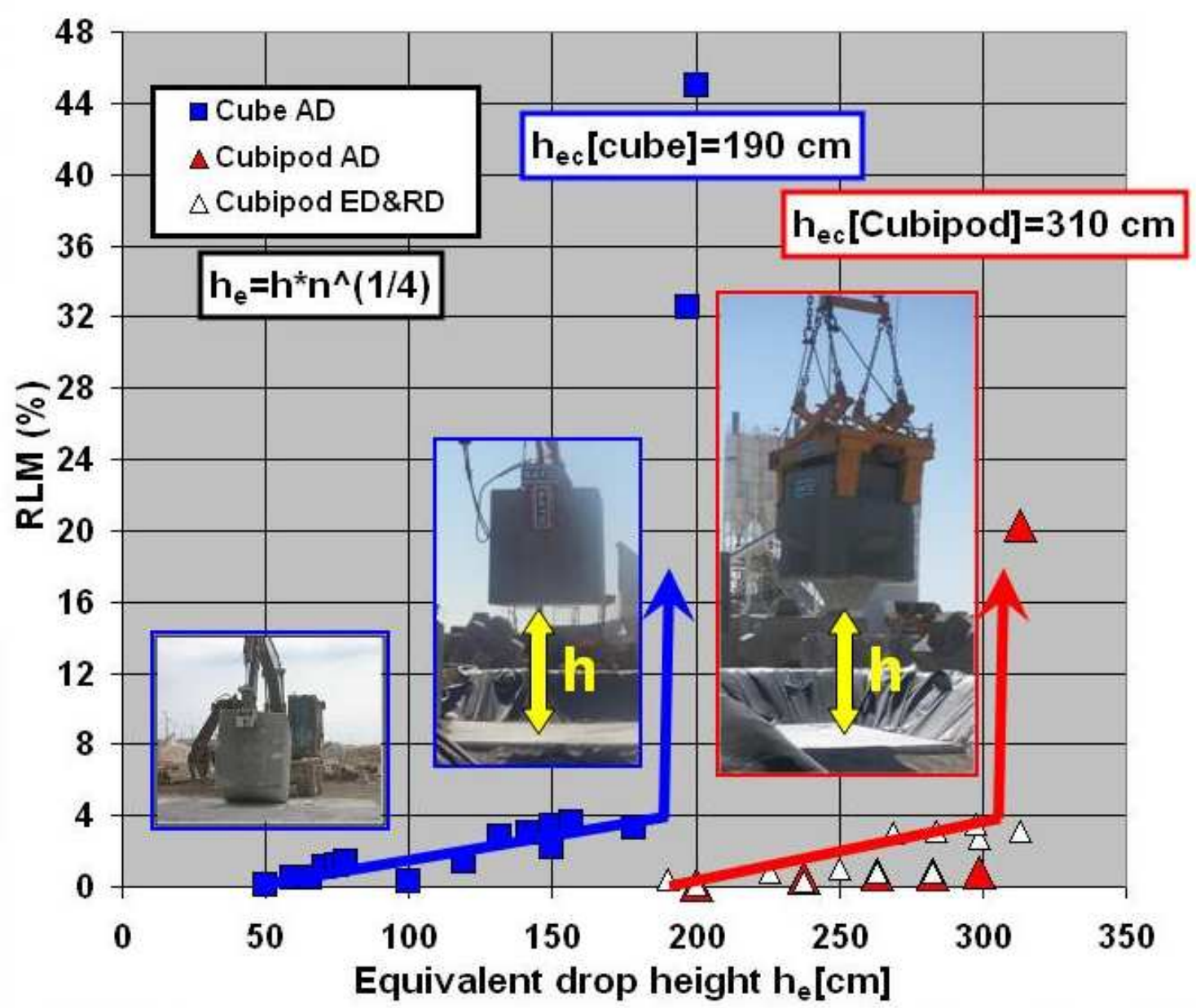

Figure 10. Relative Loss of Mass (RLM) in free fall tests with cubes and Cubipods on stiff reinforced concrete platform as function of equivalent drop height.

\section{Extreme free fall tests}

After the six $\mathrm{AD}$ of a Cubipod prototype from $\mathrm{h}[\mathrm{m}]=3.0$, the free fall platform was severely damaged and was no longer a robust and stiff platform. However, the overturning platform was in almost perfect condition after the series of overturning tests described above. Thus, extreme free fall tests were designed so that Cubipods fell onto a group of Cubipod receptors placed on the overturning platform, emulating an accidental CAU fall during construction.

Two Cubipod prototypes were dropped from $\mathrm{h}[\mathrm{m}]=8.5$ for Extreme Anvil Drop (EAD) and $\mathrm{h}[\mathrm{m}]=9.5$ for Extreme Edge Drop (EED) to fall on a group of four 16-tonne prototype Cubipod receptors. The drop heights corresponded to the maximum elevation of the gantry crane and the four prototype CAU receptors were the Cubipods used in the overturning tests, which had only negligible damage (RLM>0.3\%) after the series of overturning tests.

Fig. 11 shows a scheme of the extreme free fall tests. The drop height $(\mathrm{h}[\mathrm{m}]=8.5$ and 9.5$)$ is also defined as the minimum distance between the CAU to be dropped and the reinforced concrete platform; however, the lower part of the falling Cubipod prototype hit the upper part of the group of Cubipod receptors. Therefore, the impact energy corresponds approximately to drop heights $\mathrm{h}[\mathrm{m}]=7.0$ and 8.0 for EAD and EED, respectively.

EAD was carried out first, weighing the five 16-tonne Cubipod prototypes involved in the test before and after EAD to estimate RLM. The five Cubipod prototypes were slightly damaged $(0.1 \%<\mathrm{RLM}<2.4 \%)$. Later, the platform and the four Cubipod prototype receptors were cleaned and regrouped for EED. Again the observed damages did not significantly affect the Cubipod typology $(0.1 \%<\mathrm{RLM}<1.1 \%)$. Apparently, the impact energy was distributed randomly among the five prototypes involved in the impact, causing damages below the critical level (RLM=4\%), which 
corresponds to the critical drop height $h_{c}[m]=3.1$. Fig. 12a shows the group of four Cubipod prototype receptors placed on the platform, and Fig. 12b shows a general view of the EAD tests a few seconds before the prototype is dropped.

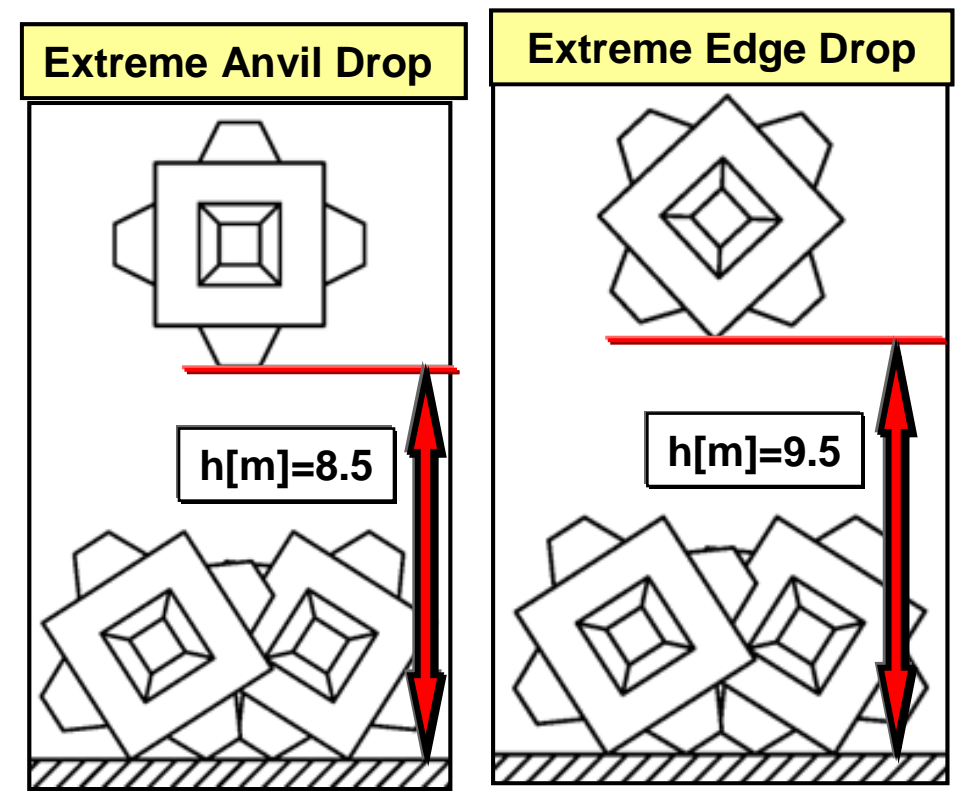

Figure 11. Scheme of the Extreme Anvil Drop (EAD) and Extreme Edge Drop (EED).
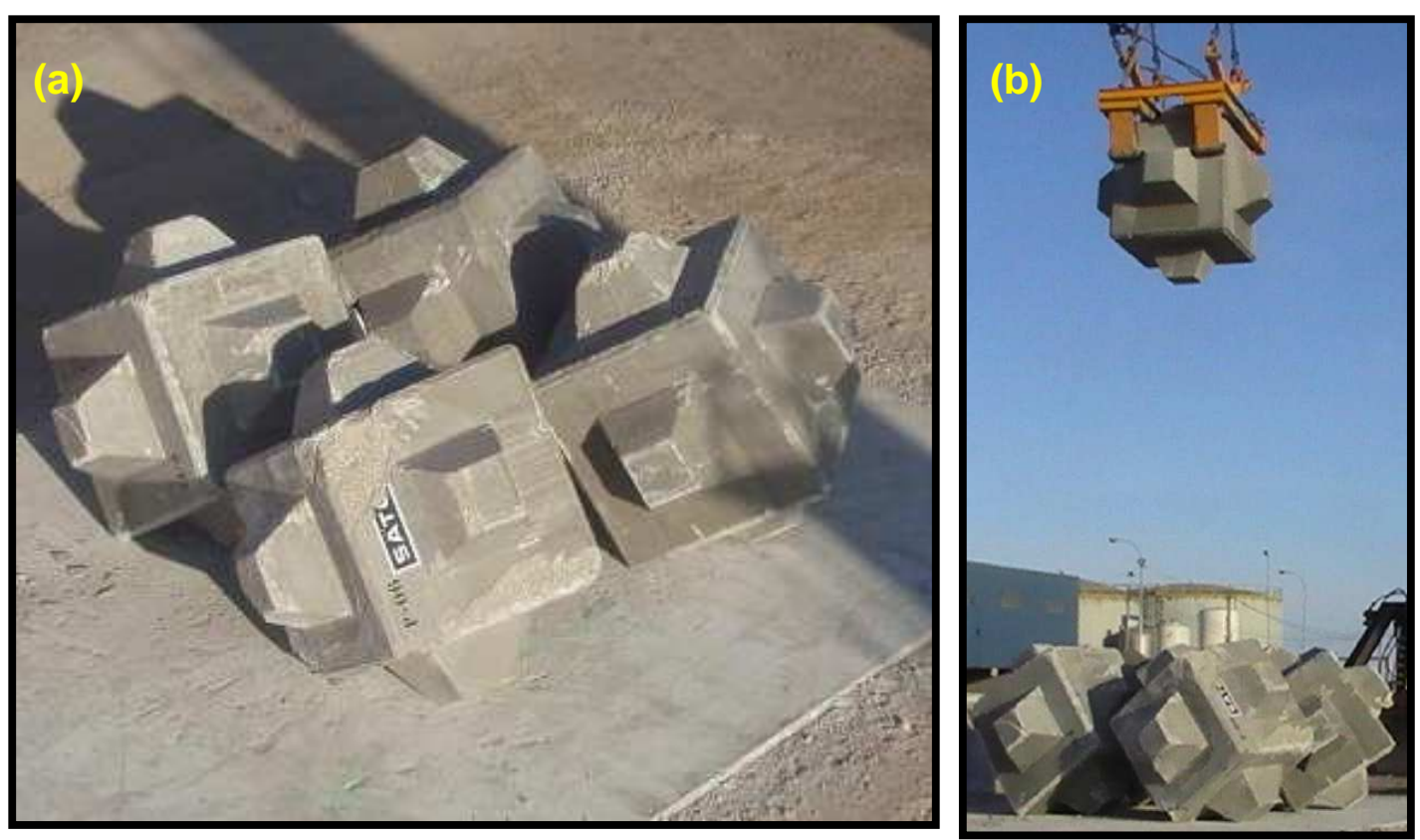

Figure 12. Extreme Anvil Drop (EAD) test: (a) prototype receptors on the platform and (b) general view.

\section{SUMMARY AND CONCLUSIONS}

Unreinforced CAUs are usually preferred worldwide; however, CAU integrity must be guaranteed during construction and service time. Structural resistance of CAU depends on the concrete supply and a variety of static, hydrodynamic and impact loads. Stresses in CAUs increase with CAU size; therefore, large unreinforced massive CAUs or fully reinforced CAUs are preferred in rough seas and non-breaking conditions. This paper reports on results from the prototype drop tests carried out to assess the structural strength of conventional cubic block and Cubipod CAUs. 
There are numerous impact loads on CAUs such as impacts during transportation, handling and placement during construction as well as collisions due to rocking CAUs in service time. Numerical models and small-scale drop tests including strain measurements are not very reliable to assess CAU integrity at prototype scale; therefore, experimental impact tests at prototype scale are considered more realistic. This paper describes overturning tests on a robust reinforced concrete platform $(10.0 \times 7.5 \times 0.9$ $\mathrm{m}$.) and free fall tests on a very robust reinforced concrete platform covered with a $20 \mathrm{~mm}$ steel plate. The damage to prototypes was measured weighing the CAUs with a load cell before and after each drop or series of overturning maneuvers; the loss of mass corresponding to each test was measured and the Relative Loss of Mass (RLM) calculated.

15-tonne conventional cube prototypes and 16-tonne Cubipod prototypes were manufactured using a vertically lifted articulated mold specifically designed to reach the same production rate of conventional cubic blocks ( 2 units per day). The Cubipod casting system has two parts: (1) a static base and (2) an upper part with six articulated elements; the concrete is poured and vibrated in two phases. The upper part can be lifted six hours after vibration. Additionally, pressure clamps were adapted for the efficient handling of the 16-tonne Cubipod units during the prototype drop tests.

In order to determine the effects of low intensity impacts on cube and Cubipod CAUs, a wheeled excavator maneuvering on the overturning platform was used. Four Cubipods were tested for frontal and diagonal overturning, and two cube prototypes were tested for partial and complete overturning. The Relative Loss of Mass (RLM) was lower than $2 \%$ for cubic blocks and lower than $0.3 \%$ for Cubipods. All prototypes maintained approximately the original geometry; cubes showed only minor edge damages and damage to Cubipod prototypes was negligible.

In order to assess the CAU structural strength with high energy impacts, three different types of free fall tests were carried out on the corresponding free fall platform using a gantry crane. The Anvil Drop (AD) causes a translation face-to-face impact, the Edge Drop (ED) induces a translation edge-toface impact, and the Random Drop (RD) generates a rotation and unpredictable translation impact on the platform. Each prototype CAU was dropped up to six times from a given drop height $(\mathrm{h}[\mathrm{m}])$ in $\mathrm{AD}$, ED or RD. Damage measured by RLM depended on CAU type (cube or Cubipod), drop type (AD, ED or RD), drop height (h) and number of repetitions (n). There is a different critical equivalent drop height, $\mathrm{h}_{\mathrm{ec}}$ for each CAU which produces an $\mathrm{RLM}=4 \%$. Below this critical value, $\mathrm{h}_{\mathrm{e}}<\mathrm{h}_{\mathrm{ec}}$ and $\mathrm{RLM}<4 \%$, the damage to the CAU increases almost linearly with $h_{e}$; damage does not affect the CAU core, but only the edges and periphery without changing significantly the original CAU morphology. On the contrary, if the critical value is surpassed, $h_{e}>h_{e c}$ and $R L M>>4 \%$, the damage to the CAU increases abruptly, the CAU core breaks, and the original CAU morphology is significantly altered. When RLM exceeds $4 \%$, CAU core breakage occurred in both cubic blocks and Cubipods. Results from free fall tests indicate that 16-tonne Cubipod prototypes withstood drops over 50\% higher than conventional 15tonne cube prototypes, with a critical equivalent drop height $h_{\mathrm{ec}}[\mathrm{m}]_{\text {Cubipod }}=3.1>\mathrm{h}_{\mathrm{ec}}[\mathrm{m}]_{\text {cube }}=1.9$.

Extreme free fall tests were designed so that the Cubipods hit a group of Cubipod prototype receptors placed on the overturning platform, emulating an accidental CAU fall during construction. Two Cubipod prototypes were dropped from $\mathrm{h}[\mathrm{m}]=8.5$ for Extreme Anvil Drop (EAD) and $\mathrm{h}[\mathrm{m}]=9.5$ for Extreme Edge Drop (EED) to land on a group of four 16-tonne prototype Cubipod receptors. EAD was carried out first showing $0.1 \%<\mathrm{RLM}<2.4 \%$ and later EED with $(0.1 \%<\mathrm{RLM}<1.1 \%)$; damages did not significantly change the Cubipod typology. Impact energy of extreme free fall tests was apparently distributed among the five prototypes involved in the impact, causing slight damage below the critical level, RLM=4\%.

Cubipod and conventional cubic block CAUs have similar stacking and handling procedures as well as manufacturing cycle time. Both are massive CAUs with similar structural strength, although the prototype drop tests have proved Cubipod CAUs withstood significantly higher drops than conventional cubes of the same size, concrete and manufacturing procedure.

\section{ACKNOWLEDGMENTS}

The authors received financial support from CDTI (CUBIPOD Project) and are grateful to the Port Authority of Alicante and the consortium TMS for their logistic support. The authors also thank Roman Goumy for assisting with the prototype drop tests and Debra Westall and Lia Wallon for revising the manuscript. 


\section{REFERENCES}

Burcharth, H.F. 1981. Full scale dynamic testing of dolosse to destruction. Coastal Engineering, 4(3), 229-251.

Burcharth, H.F., and T. Brejnegaard-Nielsen. 1986. The influence of waist thickness of dolosse on the hydraulic stability of dolosse armour. Proceedings of $20^{\text {th }}$ International Conference on Coastal Engineering, ASCE, 1783-1796.

Burcharth, H.F., K. d'Angremond, J.W. Van der Meer, and Z. Liu. 2000. Empirical formula for breakage of dolosse and tetrapods. Coastal Engineering, 40(3), 183-206.

Burcharth, H.F., E. Maciñeira, and P. Canalejo. 2002. Model testing and reliability evaluation of the new deepwater breakwater at la Coruña, Spain. Proceedings of $27^{\text {th }}$ International Conference on Coastal Engineering, ASCE, 1581-1593.

Corredor, A., R. Torres, J.V. Miñana, E. Fernández, C.F. Menéndes, M. Santos, M.E. Gómez-Martín, R. Goumy, and J.R. Medina. 2008. CUBÍPODO: Estudios de estabilidad hidráulica 2D y 3D, estudio del remonte y rebase, diseño del encofrado y ensayos de caída de prototipos. Libro del III Congreso Nacional de la Asociación Técnica de Puertos y Costas, Puertos del Estado, 187-211 (in Spanish).

Dupray, S., and J. Roberts. 2009. Review of the use of concrete in the manufacture of concrete armour units. Proceedings of Coasts, Marine Structures and Breakwaters 2009, ICE (in press).

Gómez-Martín, M.E., and J.R. Medina. 2008. Erosion of cubes and Cubipods armour layers under wave attack. Proceedings of $30^{\text {th }}$ International Conference. on Coastal Engineering, ASCE, 34613473.

Hakenberg, R., I. Vos-Rovers, J.S. Reedijk, and M. Muttray. 2004. Structural Integrity of the Xbloc® breakwater armour units prototype and numerical droptests. Proceedings of $29^{\text {th }}$ International Conference, ASCE, 4507-4520.

Hanzawa, M., T. Kato, Y. Kishira, Y. Ozawa, Y. Niidome, T. Murakami, A. Ono, K. Hidaka, H. Yoshida, and I. Tanaka. 2006. Fully reinforced 80t Dolos and sloping top caisson in Hososhima Port. Proceedings of $30^{\text {th }}$ International Conference on Coastal Engineering, ASCE, 4805-4814.

Latham, J.-P., and J. Xiang. 2009. Application of the finite-discrete element method to dynamic stress development in armour units and armour layers. Proceedings of Coasts, Marine Structures and Breakwaters 2009, ICE, (in press).

Lillevang, O.J., and W.E. Nickola. 1976. Experimental studies of stresses within the breakwater armor piece "Dolos". Proceedings of $15^{\text {th }}$ International Conference on Coastal Engineering, ASCE, 2519-2543

Medina, J.R., M.E. Gómez-Martín, A. Corredor, R. Torres, J.V. Miñana, E. Fernández, C.F. Menéndez, and M. Santos (2009). Cube and Cubipod armour unit drop tests and cost analysis. Proceedings of Coasts, Marine Structures and Breakwaters 2009, ICE, (in press).

Medina, J.R., M.E. Gómez-Martín, A. Corredor, and M. Santos. 2010. Prototype drop tests of cube and Cubipod armour units. Journal of Waterway, Port, Coastal and Ocean Engineering, ASCE, (in press).

Melby, J.A., and G.F. Turk. 1995. CORE-LOC: Optimized concrete armor units. PIANC Bulletin $\mathrm{N}^{\mathrm{o}}$ 87, 5-19.

Muttray, M., J.S. Reedijk, I. Vos-Rovers, and P. Bakker. 2005. Placement and structural strength of Xbloc $\AA$ and other single layer armour units. Proceedings of Coastlines, Structures and Breakwaters 2005, ICE, 556-567.

Nishigori, W., T. Endo, K. Nemoto, Y. Noguchi, and M. Yamamoto. 1989. Similarity law of impact between model and prototype tetrapods, in Stresses in Concrete Armor Units, edited by Davidson D.D., and O.T. Magoon, ASCE, 107-122.

Silva, M.A.G. 1983. On the mechanical strength of cubic armour blocks. Proceedings of Coastal Structures '83, ASCE, 259-271. 